\title{
Helminths infecting Dryadosaura nordestina (Squamata: Gymnophthalmidae) from Atlantic Forest, northeastern Brazil
}

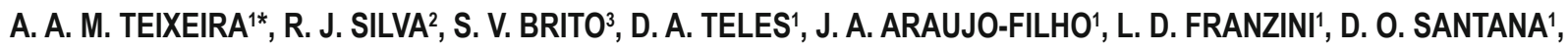 \\ W. O. ALMEIDA', D. O. MESQUITA ${ }^{1}$
}

1Programa de Pós-Graduação em Ciências Biológicas (Zoologia), Departamento de Sistemática e Ecologia - DSE, Centro de Ciências Exatas e da Natureza - CCEN, Universidade Federal da Paraíba - UFPB, Cidade Universitária, Campus I, CEP 58059-900, João Pessoa, PB, Brazil, *E-mail: adoniasteixeira01@gmail.com; ${ }^{2}$ Universidade Estadual Paulista-UNESP, Campus Botucatu, Instituto de Biociências, Departamento de Parasitologia, CEP 18618-000, Botucatu, São Paulo, Brasil; ${ }^{3}$ Centro de Ciências Agrárias e Ambientais, Universidade Federal do Maranhão, Boa Vista, CEP 65500-000, Chapadinha, MA, Brazil; 'Departamento de Ciências Biológicas, Universidade Regional do Cariri - URCA, Rua Cel. Antônio Luiz, 1161, Campus Pimenta, CEP 63105-000, Crato, CE, Brazil

\section{Article info}

Received February 20, 2018 Accepted June 7, 2018

\begin{abstract}
Summary
We analyzed the patterns of infection by helminths in populations of the Gymnophthalmidae lizard Dryadosaura nordestina from three Atlantic Forest fragments in Northeast Brazil. Prevalence and mean intensity of infection by location showed the following results: ARIE Mata de Goiamunduba (60.8 \% and $10.4 \pm 8$ ), RPPN Engenho Gargaú (83.3 \% and $20.8 \pm 19.7$ ) and Benjamim Maranhão Botanical Garden $(70.4 \%$ and $7.78 \pm 5.8)$. We provide the first records of helminth infection for the lizard $D$. nordestina, in which three species of nematodes, Aplectana sp., Cosmocerca sp. and Physaloptera lutzi and one trematode Haplometroides odhneri were recovered. Trematodes of the genus Haplometroides were previously known as parasites only in snake and amphisbaenian hosts in South America. Now, our study provides the first record of a species belonging to this genus parasitizing lizards. In conclusion, our study shows that $D$. nordestina have a depleted helminth fauna (three species at maximum), similar to other studies with lizards of this family in Brazil and that its parasite abundance is related to host snout-vent length, but not to the sex.
\end{abstract}

Keywords: nematode, trematode, lizard, parasitism

\section{Introduction}

Habitat fragmentation processes are identified as the main causes of extinction of animal and plant species (Pimm \& Raven, 2000). This occurs because many species belonging to a particular habitat are restricted to small portions of the same. Thus, as areas are being lost, extinction rates tend to rise dramatically (Pimm \& Raven, 2000; Rocha et al., 2006). Considering parasite communities, environmental changes have a faster and devastating effect, compared to free-living organisms, and they may be extinct before their hosts (Lyles \& Dobson, 1993).

According to Pinto et al. (2006) the main way to ensure the preser- vation of the biodiversity of the Brazilian Atlantic Forest will be with ecosystem management activities. However, the strategies, actions, and necessary interventions are hampered by the lack of knowledge about the ecology of the species and the functioning of the ecosystems where they are inserted (Pinto et al., 2006). In addition, knowing that parasites play an important role in the balance of ecosystems (Freeland \& Boulton, 1992; Lafferty \& Kuris, 2005), studies addressing the host-parasite relationships are also important to propose and develop strategies for management and conservation of biodiversity (Marcogliese, 2004).

Parasitological studies involving Gymnophthalmidae lizards in Brazil still remain scarce and mostly focused on records of new

\footnotetext{
* - corresponding author
} 
hosts (Ávila \& Silva, 2010). Only 14 Gymnophthalmidae of the 93 species occurring in Brazil have some kind of investigation on the host-parasite relationship (Ávila \& Silva, 2011; Ávila et al., 2010b; Brito et al., 2014; Bursey \& Goldberg, 2004; Goldberg et al., 2007a; Goldberg et al., 2007b; Oliveira et al., 2017; Neta \& Ávila, 2018; Ribeiro et al., 2018).

Dryadosaura Rodrigues, Xavier Freire, Machado Pellegrino \& Sites, 2005 is a genus composed of only one species that occurs in the Northeast part of the Atlantic Forest of Brazil, distributed in the states of Rio Grande do Norte to Bahia (Oliveira \& Pessanha, 2013). Dryadosaura nordestina Rodrigues, Xavier Freire, Machado Pellegrino \& Sites, 2005 is a small lizard, with body size (Snout-vent length) ranging from $45.4 \pm 5.7 \mathrm{~mm}$ for males and $42.7 \pm 7.1 \mathrm{~mm}$ for females, it is an active forager with generalist diet, composed mainly of arthropods, being ants and insect larvae the main food items (Garda et al., 2014). However, there are no records on parasites associated with $D$. nordestina, possibly because it is an uncommon lizard, the difficult to its collection, and because there are still few specimens housed in Herpetological Collections. Thus, the main objective of our study is to know the composition of helminth species associated with $D$. nordestina, evaluating effects of sex and host body size, using samples from the Atlantic Forest, northeastern Brazil.

\section{Materials and Methods}

We collected 56 specimens of $D$. nordestina during expeditions in three localities. We collected 23 lizards in the ARIE Mata de Goiamunduba (ARIE-MG), area of 67.5 ha, located in the Bananeiras municipality $\left(-06^{\circ} 45^{\prime} 03.78^{\prime \prime S}--35^{\circ} 38^{\prime} 00.06^{\prime \prime} \mathrm{W}\right)$ in October 2016; six in the RPPN Engenho Gargaú (RPPN-EG) area of 1058.62 ha, in the Santa Rita municipality (-06 $\left.59^{\circ} 52^{\prime \prime} \mathrm{S}--34^{\circ} 57^{\prime} 30^{\prime \prime} \mathrm{W}\right)$ in September 2016 and 27 lizards at the Benjamim Maranhão Botanical Garden (BMBG) area of 471ha, in the João Pessoa municipality ( $-07^{\circ} 08^{\prime} 08^{\prime \prime} S$ - $\left.-34^{\circ} 51^{\prime} 37^{\prime \prime} \mathrm{W}\right)$ in November 2016 (Dias et al., 2006). All areas are remnants of Atlantic Forest located in the Paraíba state, Brazil. The average annual rainfall of the areas is $1490 \mathrm{~mm}$ and the average annual temperature of $24.6^{\circ} \mathrm{C}$. All specimens were captured manually or using pitfall-traps (25 sets in each area), constructed with four buckets (20L) arranged in " $Y$ " shape, totalizing 100 buckets per area (Oliveira et al., 2017).

Lizards were killed with a lethal injection of $2 \%$ lidocaine hydrochloride and measured snout-vent length (SVL) with digital calipers. Subsequently, they were sexed, preserved in $10 \%$ formalin, and stored in $70 \%$ alcohol. In the laboratory, we removed the respiratory and gastrointestinal tracts that were surveyed for endoparasites under a stereomicroscope. The endoparasites were cleared in Hoyer's solution (Everhart, 1957), counted, registered the site of infection, and subsequently identified in accordance to Anderson (2009) for nematodes and (Silva et al., 2007) for trematode species. Subsequently, they were preserved in $70 \%$ alcohol and deposited in "Coleção de Invertebrados Paulo Young", in the
Universidade Federal da Paraíba, Brazil (UFPB-NEM: 03, 04; UFPB-DIG: 03, 04, 05).

The infection rates were calculated according to Bush et al. (1997), where prevalence of infection corresponds to the number of infected hosts divided by the total number of hosts in the sample $x 100$ (it appears in percentages throughout the text) and mean intensity of infection (MII) is the total number of parasites found in a sample, divided by the number of hosts infected with that parasite; finally, parasite abundance is defined as the total number of parasites found in a sample (individual host, host population and/or host community) Throughout the text, means appear $\pm 1 S D$.

To verify the influence of sex and host size (SVL) on the abundance of endoparasites Generalized linear mixed models - GLMM were used. This model was chosen due to the possibility of introducing into the equation random factors, thus removing possible effects that they may exert on the fixed variables (Bates, 2014).

Knowing that our sampling corresponds to three distinct component communities, to test the hypotheses suggested above, we adopted the study areas as random factors, in order to remove any influence of the locality on our dataset.

In order to verify if the abundance of endoparasites varies between the sexes of the hosts, we performed a GLMM adopting the locality and the body size (SVL) of the hosts as random factors. On the other hand, to verify the relationship between the abundance of endoparasites and the body size of the hosts (SVL), we adopted the locality and sex of the hosts as random factors.

Also, GLMM's were performed in R software with the help of packages "Ime4" (Bates, 2014) and "MuMIn" (Barton, 2009) adopting the Poisson (link:log) distribution family (Wilson \& Grenfell, 1997).

\section{Ethical Approval and/or Informed Consent}

The present research has complied with all the relevant national regulations and institutional policies for the care and use of animals. Permits for capturing of the lizards and analyzing of the endoparasites used in this study were released by SISBIO-IBAMA (no: 54378/3, authentication code: 78752298; no: 56863-1, authentication code: 47783645), SUDEMA (no: 004/2016, process no. 5376/16), and Benjamim Maranhão Botanical Garden-BMBG (no: 003/2016/JBBM/SUDEMA).

\section{Results}

We examined $56 D$. nordestina specimens, of which 33 were adult males (SVL: $40.4 \pm 10.6$ ), 14 adult females (SVL: $39.4 \pm 10.5$ ), and nine juveniles (SVL: $20.8 \pm 10.2$ ). Prevalence and mean intensity of infection in lizards by location, respectively, were: ARIE-MG (60.8 \% and $10.4 \pm 8)$, RPPN-EG (83.3 \% and $20.8 \pm 19.7)$, and $\operatorname{BMBG}(70.4 \%$ and $7.78 \pm 5.8)$.

We identified three nematode species, Aplectana sp. Railliet and Henry, 1916; Cosmocerca sp. Diesing, 1861, and Physaloptera Iutzi Cristofaro, Guimarães and Rodrigues, 1976; and also, one 
Table 1. Parasitological data from populations of Dryadosaura nordestina from Atlantic Forest, northeastern Brazil, infected by helminths.

\begin{tabular}{|c|c|c|c|c|c|c|c|c|c|c|c|c|}
\hline \multirow[b]{2}{*}{ Locality } & \multicolumn{3}{|c|}{ Aplectana sp. } & \multicolumn{3}{|c|}{ Cosmocerca sp. } & \multicolumn{3}{|c|}{ Physaloptera lutzi } & \multicolumn{3}{|c|}{ Haplometroides odhneri } \\
\hline & $\%$ & II (Range) & SI & $\%$ & II (Range) & $\mathrm{SI}$ & $\%$ & II (Range) & SI & $\%$ & II (Range) & $\mathrm{SI}$ \\
\hline RPPN-EG & 83.3 & $17.8 \pm 5.7$ & S; S.I; L.I & 16.7 & 1 & S.I & - & - & - & 33.3 & $(3-11)$ & S; S.I \\
\hline ARIE-MG & 56.5 & $5.2 \pm 3.7$ & S; S.I; L.I & - & - & - & 26.1 & $12 \pm 4.8$ & $S$ & 13 & 6 & $S$ \\
\hline BMBG & 70.4 & $7 \pm 5$ & S; S.I; L.I & - & - & - & - & - & - & 14.8 & $4 \pm 2.3$ & S.I \\
\hline
\end{tabular}

Prevalence (\%), Mean intensity of infection - II, Site of infection - SI: Stomach - S, Small intestine - S.I and Large intestine - L.I.

trematode species, Haplometroides odhneri Ruiz and Perez, 1959 infecting $D$. nordestina (Table 1).

The GLMM did not find significant differences in relation to the sex of the hosts and the endoparasites abundance $\left(R^{2}=0.01235937\right.$; $\left.Z_{1,34}=0.668 ; P=0.504\right)$, however, revealed a significant relationship between endoparasites abundance and SVL $\left(R^{2}=0.4674977\right.$; $\left.Z_{1,34}=8.377 \mathrm{P}<2 \mathrm{e}-16\right)$

\section{Discussion}

Our results provide the first records of helminth infection for the lizard $D$. nordestina, in which three species of nematodes (Aplectana sp., Cosmocerca sp. and $P$. lutzi) and one trematode (H. odhneri) were recovered.

Nematodes belonging to the family Cosmocercidade infect amphisbaenians (Amorim et al., 2017), lizards (Ávila \& Silva, 2010), and frogs (Gomez et al., 2017) and they have a monoxenic life cycle, in which their infective stages are transmitted directly via tegument or accidental ingestion (Anderson, 2000). This characteristic of transmission may explain the high prevalence of infection by Aplectana sp. in all sampled areas (Table 1), considering that the adaptations presented in Gymnophthalmidae lizards for fossorial and semi-fossorial life (Garda et al., 2014; Grizante et al., 2012; Oliveira et al., 2018) may facilitate the process of infection with parasites that have a direct life cycle (Oliveira et al., 2017). On the other hand, Cosmocerca sp. presented low infection rates, corroborating the results obtained by Bursey \& Goldberg (2004) for Gymnophthalmidae lizards from Amazonia, which showed prevalence varying between $16-36 \%$ and mean infection of intensity inferior to two. Thus, knowing that monoxenic nematodes can have their infection process favored by the ecology of Gymnophthalmidae lizards (Garda et al., 2014; Grizante et al., 2012; Oliveira et al., 2018), in case of Cosmocerca sp., historical factors (phylogeny) can be pointed out as one of the main determinants that explain the low infection rates presented here (Poulin, 2007; Brito et al., 2014).

Poulin (1998) states that there is a trade-off between the performance and range of host species that a parasite can exploit. This can easily be perceived for nematodes of the genus Physaloptera, since they infect a wide range of lizards in South America (Ávila \& Silva, 2010; Teixeira et al., 2017), however, almost always followed by low prevalence of infection: P. lutzi (0.9 \%) parasitizing Ameivula ocellifera (Spix, 1825) (Ribas et al., 1995); P. lutzi
(2 \%) and P. retusa Rudolphi, 1819 (3.9 \%) in Ameiva ameiva (Linnaeus, 1758) (Ribas et al., 1998); P. retusa (5.3\%) and P. lutzi (19.3\%) in the lizard Tropidurus hispidus (Spix, 1825) (Anjos et al., 2012); P. retusa (9 \%) registered in Polychrus acutirostris Spix, 1825 (Araujo Filho et al., 2014); P. retusa in the sympatric lizards Hemidactylus mabouia (Moreau de Jonnès, 1818) (3.94\%) and Phyllopezus pollicaris (Spix, 1825) (2.54 \%) (Sousa et al., 2014); Physalopreta sp. (5\%) in the stomach of Iguana iguana (Linnaeus, 1758) (Teles et al., 2017) and more recently, $P$. lutzi registered by Lima (2017) parasitizing the gecko lizards P. pollicaris (3\%), Hemidactylus brasilianus (Amara, 1935) (4.1\%), Hemidactylus agrius Vanzolini, 1978 (1.6 \%), Gymnodactylus geckoides Spix, 1825 (12.6\%), and Lygodactylus klugei (Smith, Martin e Swain, 1977) (1.5 \%), from northeastern Brazil. Thus, the low infection rates presented here by the generalist nematode $P$. lutzi apparently obey the standard cited above. However, further testing is needed to verify if this hypothesis truly fits the patterns of infection exhibited by the parasitic nematode species of lizards in the Neotropical region.

Trematodes of the genus Haplometroides Odhner, 1910 were previously known as parasites only in snake and amphisbaenian hosts in South America (Silva \& Barrella, 2002; Silva et al., 2005a,b; 2007;2008; Santos et al., 2008). Now, our study provides the first record of $H$. odhneri parasitizing lizards.

Our study did not reveal significant differences between the sexes of the lizards in relation to the abundance of endoparasites, similar to the results obtained for other Gymnophthalmidae lizards by Neta \& Ávila (2018) for Colobosauroides cearensis Cunha, Lima-Verde e Lima, 1991 and Ribeiro et al. (2018) for Nothobachia ablephara Rodrigues, 1984. However, to populations of Anotosaura vanzolinia Dixon, 1974 from Caatinga, females were more infected them males, since they tend to use more humid habitats during their reproductive period, potentializing the process of infection by the monoxenic nematode Oswaldocruzia brasiliensis Lent et Freitas, 1935 (Oliveira et al., 2017).

Usually, juvenile hosts tend not to be parasitized or harbor a reduced parasite load when compared to adult individuals, due to the shorter exposure time the sources of infection (Kuris et al., 1980). In conformation with this theory, no juvenile lizard in our sample was parasitized.

According to Nascimento (2004), larger hosts harbor a larger parasitic load, because they present a larger area and possibly more resources for the establishment of parasite populations. Our study 
corroborates this hypothesis since we observed a significant relationship between SVL and the abundance of parasites in the lizard D. nordestina, similar to Neta \& Ávila (2018) for C. cearensis in a Caatinga area, northeast of Brazil.

Small lizards may restrict the diversity of associated endoparasites, since niche differentiation and microhabitat segregation by competing parasite species may be impaired by the reduced size of the host (Ávila et al., 2010a; Kuris et al., 1980; Oliveira et al., 2017). For lizards, this hypothesis is supported mainly by Gymnophthalmidae: Cercosaura eigenmanni (Griffin, 1917 ) and C. oshaughnessyi (Boulenger, 1885) both parasitized by three taxa of parasites (Bursey \& Goldberg, 2004); Micrablepharus maximiliani (Reinhardt e Luetken, 1862) also parasitized by three taxa of parasites (Brito et al., 2014); A. vanzolinia parasitized by only one species of nematode (Oliveira et al., 2017); N. ablephara with three gastrointestinal helminth taxa identified (Ribeiro et al., 2018) and $C$. cearensis infected with five gastrointestinal helminth taxa (Neta \& Ávila, 2018).

In conclusion, our study shows that $D$. nordestina have a depleted helminth fauna (three species at maximum) composed of nematodes and trematodes and that its parasite abundance is related to host SVL, but not to the sex.

\section{Conflict of Interest}

Authors state no conflict of interest.

\section{Acknowledgments}

We would like to thank Ávila RW and Silva, CF for help in identifying nematodes and trematodes. We thank CAPES for research fellowships to AAMT and LDF and CNPq for research fellowships to WOA (PQ-302429/2015-8), DOM (306541/2017-3), DOS, JAAF, and DAT. The help of the employees of RPNN- EG, and BMBG is also acknowledged. RJS is supported by FAPESP \#2016/503771; CNPq \#309125/2017-0, and CNPq-PROTAX \#440496/2015-2. Finally, we thank for useful comments and suggestions on the manuscript.

\section{References}

Amorim, D.M., Silva, L.A.F., Morals, D.H., Silva, R.J., Ávili, R.W. (2017): Aplectana nordestina n. sp. (Nematoda: Cosmocercidae) parasitizing Leposternon polystegum (Squamata: Amphisbaenidae) from Northeastern, Brazil. Zootaxa, 4247, 83 - 88. DOI: 10.11646/zootaxa.4247.1.12

Anderson, R.C. (2000): Nematode parasites of vertebrates: their development and transmission, 2nd Edition edn. New York, CABI Publishing, 650pp.

Anderson, R.C., Chabaud, A.G., Willmott, S. (2009): Keys to the Nematode Parasites of Vertebrates: Archival Volume, CABI. Anjos, L.A., Ávila, R.W., Ribeiro, S.C., Almeida, W.O., Silva, R.J.
(2012): Gastrointestinal nematodes of the lizard Tropidurus hispidus (Squamata: Tropiduridae) from a semi-arid region of northeastern Brazil. J. Helminthol., 81, 443 - 449. DOI: 10.1017/ S0022149X12000491

Araujo Filho, J.A., Ribeiro, S.C., Brito, S.V., Teles, D.A., SouSA, J.G.G., Ávila, R.W., Almeida, W.O. (2014): Parasitic nematodes of Polychrus acutirostris (Polychrotidae) in the Caatinga biome, Northeastern Brazil. Braz. J. Biol., 74, 939 - 942. DOI: 10.1590/1519-6984.01313

Ávila, R.W., Anjos, L.A., Gonçalves, U., Freire, E.M.X., AlmelDA, W.O., SiLVA, R.J. (2010a): Nematode infection in the lizard Bogertia lutzae (Loveridge, 1941) from the Atlantic forest in north-eastern Brazil. J. Helminthol., 84, 199 - 201. DOI: 0.1017 I S0022149X09990538

ÁvILA, R.W., SILVA, R.J. (2010): Checklist of helminths from lizards and amphisbaenians (Reptilia, Squamata) of South America. J. Venom. Anim. Toxins. incl. Trop. Dis., 16, 543 - 572. DOI: 10.1590/ S1678-91992010000400005

ÁvILA, R.W., SILVA, R.J. (2011): Helminths of lizards (Reptilia: Squamata) from Mato Grosso State, Brazil. Comp. Parasitol., 78, 129 - 139. DOI: 10.1654/4473.1

ÁvILA, R.W., SouzA, F.L., Silva, R.J. (2010b): Helminths from Seven Species of Lizards (Reptilia: Squamata) at the Cerrado of Mato Grosso do Sul State, Brazil. Comp. Parasitol., 77, 67 - 71. DOI: $10.1654 / 4414.1$

BARTON, K. (2009): MuMIn: multi-model inference. R package version 1. 0. 0. http://r-forge.r-project.org/projects/mumin.

Bates, D., Mächler, M., Bolker, B.M., Walker, S.C. (2014): Fitting linear Mixed-Effects Models Using Ime4. J. Stat. Softw., 67, 1 - 48. DOI: 10.18637/jss.v067.i01

Brito, S.V., Corso, G., Almeida, A.M., FerreiRa, F.S., Almeida, W.O., Anjos, L.A., Mesquita, D.O., Vasconcellos, A. (2014): Phylogeny and micro-habitats utilized by lizards determine the composition of their endoparasites in the semiarid Caatinga of Northeast Brazil. Parasitol. Res., 113, 3963 - 3972. DOI: 10.1007/s00436-0144061-Z

Bursey, C.R., Goldberg, S.R. (2004): Cosmocerca vrcibradici n. sp.(Ascaridida: Cosmocercidae), Oswaldocruzia vitti n. sp.(Strongylida: Molineoidae), and other helminths from Prionodactylus eigenmanni and Prionodactylus oshaughnessyi (Sauria: Gymnophthalmidae) from Brazil and Ecuador. J. Parasitol., 90, 140 - 145. DOI: 10.1645/GE-3234

Bursey, C.R., Goldberg, S.R., Telford, S.R. (2006): New species of Aplectana (Nematoda: Cosmocercidae) and Mesocoelium monas (Digenea: Brachycoeliidae) in Lepidophyma flavimaculatum (Squamata: Xantusiidae) from Costa Rica. Caribb. J. Sci., 42, $164-170$

Bush, A.O., Lafferty, K.D., Lotz, J.M., Shostak, A.W. (1997): Parasitology meets ecology on its own terms: Margolis et al. revisited. J. Parasitol., 83, 575 - 583. DOI: 10.2307/3284227

Dias, S.C., Candido, D.M., Brescovit, A.D. (2006): Scorpions from Mata do Buraquinho, João Pessoa, Paraíba, Brazil, with ecologi- 
cal notes on a population of Ananteris mauryi Lourenço (Scorpiones, Buthidae). Rev. Bras. Zool., 23, 707 - 710. DOI: 10.1590/ S0101-81752006000300014

EverHART, B.A. (1957): Notes on the helminths of Pseudemys scripta elegans (Wied, 1838) in areas of Texas and Oklahoma. Proc. Okla. Acad. Sci., 38 - 43

Freeland, W.J., Boulton, W.J. (1992): Coevolution of Food Webs: Parasites, Predators and Plant Secondary Compounds. Biotropica, 24, 309 - 327. DOI: 10.2307/2388525

Garda, A.A., Medeiros, P.H.S., Lion, M.B., Brito, M.R.M., Vieira, G.H.C., MESQUiTA, D.O. (2014): Autoecology of Dryadosaura nordestina (Squamata: Gymnophthalmidae) from Atlantic forest fragments in Northeastern Brazil. Zoologia (Curitiba), 31, 418 - 425. DOI: $10.1590 /$ S1984-46702014000500002

Nascimento, M.G., Munoz, G., Marquet, P.A., Poulin, R. (2004): Testing the energetic equivalence rule with helminth endoparasites of vertebrates. Ecol. lett., 7, 527 - 531. DOI: 10.1111/j.14610248.2004.00609.x

Goldberg, S.R., Bursey, C., Vitt, L.J. (2007a): Parasite communities of two lizard species, Alopoglossus angulatus and Alopoglossus atriventris, from Brazil and Ecuador. Herpetol. J., 17, 269 - 272 Goldberg, S.R., Bursey, C.R., Caldwell, J.P., Vitt, L.J., Costa, G.C. (2007b): Gastrointestinal Helminths from Six Species of Frogs and Three Species of Lizards, Sympatric in Pará State, Brazil. Comp. Parasitol., 74, 327 - 342. DOI: 10.1654/4268.1

Gomez, M.D.P., GonzÁlez, C.E., SAnABria, E.A. (2017): A new species of Aplectana (Nematoda: Cosmocercidae) parasite of Pleurodema nebulosum (Anura: Leptodactylidae) from the Monte desert, Argentina, with a key to Neotropical species of the genus Aplectana. Zootaxa, 4247, 121 - 130. DOI: 10.11646/zootaxa.4247.2.3 GrizANTE, M.B., Brandt, R., KoHLSDORF, T. (2012): Evolution of body elongation in gymnophthalmid lizards: relationships with climate. PloS one, 7, e49772. DOI: 10.1371/journal.pone.0049772

Kuris, A.M., Blaustein, A.R., Alıo, J.J. (1980): Hosts as islands. Am. Nat., 116, $570-586$

Lafferty, K.D., KuRIS, A.M. (2005): Parasitism and environmental disturbances. In: Thomas, F., Renaud, F., GuÉGan, J.F. (Eds) Parasitism and ecosystems. New York, USA, Oxford University Press. Lima, V.F., Brito, S.V., Araujo Filho, J.A., Teles, D.A., Ribeiro, S.C., Teixeira, A.A.M., Pereira, A.M.A., AlmeidA, W.O. (2017): Helminth parasites of Phyllodactylidae and Gekkonidae lizards in a Caatinga ecological station, northeastern Brazil. Biota Neotrop., 17, 1 - 7. DOI: e20160263, 2017

LYLES, A.M., DoBSon, A.P. (1993): Infectious disease and intensive management: population dynamics, threatened hosts, and their parasites. J. Zoo Wildl. med., 24, 315 - 326

Marcogliese, D.J. (2004): Parasites: Small Players with Crucial Roles in the Ecological Theater. EcoHealth, 1, 151 - 164. DOI: 10.1007/s10393-004-0028-3

NetA, A.F.S., ÁvILA, R.W. (2018) Helminths of the lizard Colobosauroides cearensis (Squamata, Gymnophthalmidae) in an area of Caatinga, Northeastern Brazil. Acta Herpetol, 13, 29 - 34
Oliveira, B.H.S., Pessanha, A.L.M. (2013): Microhabitat use and diet of Anotosaura vanzolinia (Squamata: Gymnophthalmidae) in a Caatinga area, Brazil. Biota Neotrop., 13, 193 - 198. DOI: 10.1590/S1676-06032013000300022

Oliveira, B.H.S., Teixeira, A.A.M., QueIroz, R.N.M., Araujo Filho, J.A., Teles, D.A., Brito, S.V., MesquitA, D.O. (2017): Nematodes infecting Anotosaura vanzolinia (Squamata: Gymnophthalmidae) from Caatinga, northeastern Brazil. Acta Herpetol., 12, 103 - 108. DOI: 10.13128/Acta_Herpetol-18765

Oliveira, B.H.S., Queiroz, R.N.M., Cavalcanti, L.B.Q., Mesquita, D.O. (2018): Autecology of neotropical lizard species Anotosaura vanzolinia (Squamata, Gymnophthalmidae) in a Caatinga region, north-eastern Brazil. Herpetol. J., 28, 19 - 26

PIMm, S.L., Raven, P. (2000): Biodiversity: extinction by numbers. Nature, 403, 843 - 845. DOI: 10.1038/35002708

Pinto, L.P., Bedê, L., Paese, A., Fonseca, M., Paglia, A., Lamas, I. (2006): Mata Atlântica Brasileira: os desafios para conservação da biodiversidade de um hotspot mundial. In: Rocha, C.F.D., Bergallo, H.G., Alves, M.A.S. (Eds) Biologia da Conservação: Essências. São Carlos, São Paulo, Brasil, RIMA

PoulIN, R. (1998): Large-scale patterns of host use by parasites of freshwater fishes. Ecol. lett., 1, 118- 128

Poulin, R. (2007): Evolutionary Ecology of Parasites. Princeton, New Jersey, Princeton University Press

R Development Core Team (2013): R. A language and environment for statistical computing. R Foundation for Statistical Computing, Vienna, Austria

Ribas, S.C., Rocha, C.F.D., TeIXeIRA-Filho, P.F., Vicente, J.J. (1995): Helminths (Nematoda) of the lizard Cnemidophorus ocellifer (Sauria: Teiidae): Assessing the effect of rainfall, body size and sex in the nematode infection rates. Cienc. Cult. (São Paulo), 47, 88 - 91 Ribas, S.C., Rocha, C.F.D., TeIXEIRA-FILHO, P.F., VicENTE, J.J. (1998): Nematode infection in two sympatric lizards (Tropidurus torquatus and Ameiva ameiva) with different foraging tactics. Amphib. Reptil., 19, $323-330$

Ribeiro, L.B., Ferreira, A.C.S., Silva, D.C.N., Vieira, F.M., MouRA, G.J.B. (2018): Helminth Parasites of the Lizard Nothobachia ablephara (Gymnophthalmidae) in Caatinga Areas from the Sertão of Brazil. J. Parasitol., 104, 177 - 182. DOI: 10.1645/17-90.

RochA, C.F.D. (1995): Nematode parasites of the Brazilian sand lizard, Liolaemus lutzae. Amphib. Reptil., 16, 412 - 415

Rocha, C.F.D., Bergallo, H.G., Van Sluys, M., Alves, M.A.S., JenKINS, C. (2006): Corredores Ecolégicos e Conservação da Biodiversidade: Um Estudo de Caso na Mata Atlantica. In: RochA, C.F.D., Bergallo, H.G., Alves, M.A.S. (Eds) Biologia da Conservação. Essências. São Carlos, São Paulo, Brasil, RIMA.

Rocha, C.F.D., VRcibradic, D., Vicente, J.J., Cunha-Barros, M. (2003): Helminths infecting Mabuya dorsivittata (Lacertilia, scincidae) from a high-altitude habitat in Itatiaia National Park, Rio de Janeiro State, Southeastern Brazil. Braz. J. Biol., 63, 129 - 132. DOI: 10.1590/S1519-69842003000100017

Santos, K.R., BarRella, T.H., Zica, E.O.P., Silva, R.J. (2008): New 
reports on parasitism by Haplometroides buccicola (Digenea, Plagiorchiidae) in Brazilian snak. J. Venom. Anim. Toxins. incl. Trop. Dis., 14 (3), 527 - 532. DOI: 10.1590/S1678-9199200800030001 Silva, R.J., BédA, A.F., FerreiRA, V.L. (2008): New record of Haplometroides intercaecalis (Digenea, Plagiorchiidae) infecting a Brazilian snake. J. Venom. Anim. Toxins. incl. Trop. Dis., 14, 161 - 165. DOI: 10.1590/S1678-91992008000100013

Silva, R.J., Andrade, P.A., Monteiro e Silva, H.A., Rossellini, M., Barrella, T.H. (2005a): Report on the occurrence of Haplometroides buccicola (Trematoda, digenea, plagiorchiidae) infecting Phalotris lativittatus (serpentes, Colubridae) in Brazil. J. Venom. Anim. Toxins. incl. Trop. Dis., 11, 373 - 379. DOI: 10.1590/ S1678-91992005000300013

Silva, R.J., BARRella, T.H. (2002): Micrurus frontalis as a new host recorded for Haplometroides odhneri (Trematoda, Digenea, Plagiorchiidae). Rev. Bras. Parasitol. Vet., 11, $47-48$

Silva, R.J., Ferreira, V.L., Strüssmann, C. (2007): New species of Haplometroides (Digenea: Plagiorchiidae) from Phalotris nasutus (Gomes, 1915) (Serpentes, Colubridae). J. Parasitol., 93, 917 921. DOI: 10.1645/GE-1123R.1

Silva, R.J., Zica, E.O.P., Cruz, M., O'Reilly, J.C., Costa, M.C. (2005b): Occurrence of Haplometroides odhneri (Trematoda,
Digenea, Plagiorchiidae) infecting Leptotyphlops koppesi (Serpentes, Leptotyphlopidae). Arq. Bras. Med. Vet. Zootec., 57, 267 - 269. DOI: 10.1590/S0102-09352005000800021

SousA, J.G.G., Brito, S.V., Ávila, R.W., Teles, D.A., Araujo-Filho, J.A., TelXeira, A.A.M., Anjos, L.A., AlmeidA, W.O. (2014): Helminths and Pentastomida of two synanthropic gecko lizards, HemidactyIus mabouia and Phyllopezus pollicaris, in an urban area in Northeastern Brazil. Braz. J. Biol., 74, 943 - 948. DOI: 10.1590/15196984.01413

Teixeira, A.A.M., Brito, S.V., Teles, D.A., Ribeiro, S.C., Araujo-Filho, J.A., Lima, V.F., Pereira, A.M.A., Almeida, W.O. (2017): Helminths of the Lizard Salvator merianae (Squamata, Teiidae) in the Caatinga, Northeastern Brazil. Braz. J. Biol., 77, 312 - 317. DOI: 10.1590/1519-6984.13515

Teles, D.A., Brito, S.V., Teixeira, A.A.M., RibeiRo, S.C., Araujo Filho, J.A., Lima, V.F., Pereira, A.M.A., Almeida, W.O. (2017): Nematodes associated with Iguana iguana (Linnaeus, 1758) (Squamata, Iguanidae) in Semi-arid areas of Northeastern Brazil. Braz. J. Biol., 77, 514 - 518. DOI: 10.1590/1519-6984.17615

Wilson, K., Grenfell, B.T. (1997): Generalized Linear Modelling for Parasitologists. Parasitol. Today., 13, 33 - 38. DOI: 10.1016/ S0169-4758(96)40009-6 